\title{
Problems Encountered by Religious Vocational Secondary School and Other Secondary School Students in Physical Education and Sports Activities
}

\author{
Mustafa Bar ${ }^{1, *}$, Menzure Sibel Yaman², Gülten Hergüner ${ }^{3}$ \\ ${ }^{1}$ Institute of Educational Sciences, Physical Education and Sports, Sakarya University, Turkey \\ ${ }^{2}$ Institute of Health Sciences, Physical Education and Sports, Gazi University, Turkey \\ ${ }^{3}$ Faculty of Physical Education and Sports, Sakarya University, Turkey
}

Copyright $\subseteq 2016$ by authors, all rights reserved. Authors agree that this article remains permanently open access under the terms of the Creative Commons Attribution License 4.0 International License

\begin{abstract}
The study aimed to determine problems encountered by Religious Vocational Secondary School and other Secondary School students in physical education and sports activities and to compare these problems according to school type and gender. A questionnaire named "Problems encountered in attending to physical education and sports activities" developed by the researchers was applied. A Religious Vocational Secondary School selected with random method in Sakarya Province and a Secondary School selected from other Secondary Schools was determined for the research. Questionnaire form was applied to 400 volunteer students in total. Frequency analysis and Chi-square analysis were used. It was found out that male students encountered with more problems than female students regarding their school lives, organizations and institutions and families. Moreover, problems regarding school lives in Religious Vocational Secondary School and other Secondary School students had similarities; however, problems regarding organizations and institutions as well as families were experienced more frequently in other Secondary Students than Religious Vocational Secondary School students. In conclusion, male students and other Secondary School students experience problems in every field and they express these problems more frequently as they attend physical education and sports activities more than female students and Religious Vocational Secondary School students do.
\end{abstract}

Keywords Physical Education, Sports, Religious Vocational Secondary School, Problem

\section{Introduction}

There have been many definitions regarding physical education and sports within the process of sports studies. We have included some of them in our research; because this research focuses on determining problems encountered in physical education and sports activities. Therefore, the following definitions, views and texts are important for clearing up our research.

Physical education is enabling physical, mental and intellectual development of an individual in accordance with the basic principles of National Education. Games, gymnastic and sports activities, all of them, are the reflections of an individual being robust physically, being awake intellectually and being healthy mentally [1].

Physical education is a general concept including all educational physical activities such as games, gymnastic and sports and it is a training which is performed within physical activities and through physical activities [2].

Pangrazzi (2007) [3] specifies that physical education is a part of the whole education program which mainly contributes to action experiences of all children in their growing up and development periods. He expressed physical education as education through actions.

Sports regulate blood stream of the whole body and develop body health of children as well as enabling bone and muscle development healthily. During their mental development, children improve their reflexes and thinking capacities while learning their abilities and they can acquire habits of deciding fast, applying the decision and taking responsibility of the results of their decisions. Children acquire the ability to belong a group, to express themselves by socializing and most importantly to accept winning and losing at the same [4].

The sports habit varies within a wide range of purposes for an individual from having fun, resting and enjoying his/her time to protecting health, being strong, acquiring a social environment or making money [5].

Positive effects of sports, which provide opportunities for social activities and interactions, on mental health are well known. In the studies performed with children, it was stated 
that physical activities and sports have positive effect on self-esteem, depression, anxiety and behavior problems [6],[7].

In addition, physical education and sports activities enable it to smooth aggressiveness and derangement of the child who is in the process of development and change or they enable it to overcome the stress caused by monotony in adults' daily lives. When the child learns how to play the game in accordance with its rule within the game, he/she will more likely to recognize the laws and become an adjusted individual within the society. Within the game, players fight, develop tactics and take precautions for a common achievement with their teammates. They become disciplined with self-control by avoiding from behaviors that may be harmful for their team, supporters and the community they represent. The great achievement they show in the sports, their personalities and the superiority they have over their friends with their game intelligence reveal their leadership feature within the time [8].

Herguner (2015) "Sports is the performance enhancing, socializing and instructive psycho-motor activities based on mental and physical competition, assessed by the units of measurement for weight, length, time and the score, requiring planned work and obedience to the rules, performed with or without equipment, individually or as a team, by using different areas and with various purposes"[9]

It is much easier for those children who play sports to learn the importance of time and acquire discipline. When they learn this discipline and apply it in their daily lives, they will become a disciplined individual both in terms of studying and human relations and they will learn to take responsibility of their own lives. There will not be the problem of filling free time and they will get rid of the habit of spending lots of time watching TV and it will be much easier to stay away from bad habits [4].

The child finds the opportunity to have better functioning organs and systems with physical education and sports. After these developments, children possess positive physical development and health [10].

An individual comprehends the importance of health principles and action in life with the help of physical education activities. They acquire knowledge about issues such as nature of human action, the importance of sports in growing up and development, cleanliness, prevention from diseases, balanced and sufficient diet, good health habits, etc. with the accumulation of the knowledge regarding these facts, activities will gain new meanings and this will help individuals lead more healthy and purposeful life [11].It is pretty important for the future of Turkey's sports to develop basic education skills of children, to find and train successful sportsmen/sportswomen by determining their skills. For this purpose, families should believe in all benefits of the sports and give importance to school-family relationships. In short, families should possess sports culture for training their children in this issue. Families possessing sufficient information will encourage and support their children for playing sports in the most convenient way [12].
Schools are the second most socializing institutions after family. Specific sociocultural features of the school are effective in sports success of the student as well as his/her school success [13]. Schools are both education centers and places where peers come together. Therefore, schools provide wide range of opportunities in terms of physical education; since growing period of our children and youth in secondary school coincides with school age. In these periods when bodies develop, it is important to gain resistance, agility and some habits with sports [14].

Their abilities, special skills and social relations may also determine their adaptation skills. A child who had an adaptation to his/her environment in previous periods can solve the problems he/she encounters. Children's attending to sports activities and interactions, making changes in life styles and in physical or social environment are seen as significant tools for overcoming maladaptation [15].

Our schools have important tasks in extending, popularizing and encouraging physical education and sports. As long as love of sports is started within the family and reinforced at school by supporting it, an individual can create a wide base in school and mass sports [16]. As a result, attendance to physical education and sports activities increases as well. Physical education and sports activities enable individuals to recognize themselves within the activities while providing positive effects in their physical and mental education. These experiences are reflected to social life and divert the individual to undertake solution oriented social roles. Consequently, this contributes to express his/her problems and learn how to deal with them. This research was carried out depending on this point of view aims at determining problems of the students studying in secondary schools during physical education and sports activities. The next research is expected to be about anticipations and solutions regarding these problems.

The facilities belonging to the Secondary Schools in Sakarya and Sakarya Religious Vocational Secondary School, which are subjected to this research, can be stated separately as follows: There are 83 teachers and 1287 students in the general Secondary school. Two hours of physical education and two hours of exercises are in the weekly schedule. While there is a gym, an open basketball court, a volleyball court and a playground, there are also materials, which will be enough for all of the students. On the other hand, the secondary school has badminton, chess, table tennis teams for female students and football, basketball, badminton, chess, table tennis and volleyball teams for male students and these teams regularly participate in competitions between secondary schools [17].

There are 46 teachers and 847 students in the Religious Vocational Secondary-School. Two hours of physical education is in the weekly schedule and only the school teams participate in two hours of exercise. While there is no gym in the Religious Vocational Secondary School, there is an open basketball court, a volleyball court and a playground. The supplies for the physical education course and the sport activities are limited. On the other hand, there are volleyball 
and chess teams for female students and volleyball and chess teams for male students separately and the teams participate in competitions between secondary schools once in a year [18].

\section{Material and Method}

A descriptive method was used in the research which aims at revealing the current situation.

Development of the tool used in the research: The questionnaire used in the study was developed by the researchers. First, with open ended questionnaire, students were asked to write down their problems they encountered with during physical education and sports activities by reaching 100 volunteer students studying at 5th, 6th, 7th and 8th grades in a Religious Vocational Secondary School and in one of the other Secondary Schools which were determined randomly in Sakarya, in 2012-2013 educational year. Problems that they specified with their own expressions were collected by open ended questionnaire. The acquired problems were reviewed and turned into a closed ended two choice questionnaire (Yes-No) by being specified clearly. After the views of field experts were taken, the test was applied to same people with retest method. After seeing that the questionnaire is comprehensible, it was multiplied and applied to the sample group specified. 400 questionnaires which were filled in completely were considered valid.

Purpose of the research: The purpose of this research is to determine the problems of students studying at Religious Vocational Secondary Schools and other Secondary Schools during their physical education and sports activities. These students started studying at the mentioned schools in 2013-2014 academic years after the law number 6287 (30.03.2012). Article 9 took effect regarding making amendment on primary education and educational act as well as some other acts in 2012.

The main purpose is to examine the problems of students encountered during physical education and sports activities regarding their school lives, organizations and institutions and families and to find out whether the acquired results differ by personal (demographic) information of students; that is school type and gender of the students.

Problem of the research: What are the problems of students studying at Religious Vocational Secondary Schools and other Secondary Schools during physical education and sports activities regarding school life, organizations and institutions and family life? Do the problems differ by demographic information of the students?

\section{Sub-problems of the research:}

1: Are there any differences in problems by school type?

2: Are there any differences in problems by gender?

\section{Hypotheses:}

H1: There are differences in problems by school type.

$\mathrm{H} 2$ : There are differences in problems by gender.

Tables were formed and interpreted according to these results.

Significance of the research: With this research, it is significant to determine the problems of students studying at Religious Vocational Secondary Schools and other Secondary Schools during physical education and sports activities regarding school life, organizations and institutions and family life and to share the acquired data with The Ministry of National Education, Head Council of Education and Morality, The Ministry of Youth and Sports and related units. Evidently, the results of the scientific studies are directive in order to render more qualified service in education planning and reorganizing sports services. It is expected that this research has significance in terms of teaching gym lessons more efficiently and purposefully to the students studying at Religious Vocational Secondary Schools and other Secondary schools, adopting a positive sense of sports within the families and at schools by determining the effects of families and schools to perform a more convenient teaching and sports activities and creating suitable sports environments and developing education programs; moreover we also hope that this research will contribute to similar future studies within the field.

Universe of the research: The universe of the study is composed of students in the $5^{\text {th }}, 6^{\text {th }}, 7^{\text {th }}$ and $8^{\text {th }}$ grade at Religious Vocational Secondary School and the other Secondary Schools in the province of Sakarya. Secondary schools which possess lots of students and which take place within the city life in Sakarya province were taken into the scope of the research. A sample composing of 400 students in total was formed with random method from 2500 students studying at these schools.

Questionnaire of the research: First, the problems were determined and collected with open ended questionnaire regarding physical education and sports activities by randomly reaching 100 students studying in the $5^{\text {th }}, 6^{\text {th }}$, $7^{\text {th }}$ and $8^{\text {th }}$ grade at a randomly selected Religious Vocational Secondary Schools and one of the other Secondary Schools. The acquired problems were expressed clearly and a two choice closed ended questionnaire (Yes-No) was formed. The necessary amendments were made by taking opinions of field experts and these questionnaires were applied to the sample group (500 students). 400 questionnaires which were filled in completely were considered valid.

Statistical Analyses of the Research: SPSS 15.0 for Windows packet program was used in the analysis of the data acquired from the research. Frequency analysis was used in determining percentage distribution and numbers of the demographic information of the attendees. On the other hand, it was benefitted from Chi-Square analysis in comparing problems of the students experienced during 
physical education and sports activities regarding family lives, school lives, organizations and institutions by demographic differences. Significance level in Chi-Square analysis was determined as $\mathrm{p}<0,05$.

\section{Findings}

Table 1. Frequency and Percentage Distribution of the Attendees regarding their Demographic Information

\begin{tabular}{|c|c|c|c|}
\hline Variables & Sub-variables & F & $\mathbf{\%}$ \\
\hline \multirow{2}{*}{ Gender } & Female & 213 & 53,3 \\
\cline { 2 - 4 } & Male & 187 & 46,8 \\
\hline \multirow{2}{*}{ School Type } & $\begin{array}{c}\text { Religious } \\
\text { Vocational }\end{array}$ & 200 & 50,0 \\
\cline { 2 - 4 } & Secondary School & 200 & 50,0 \\
\hline
\end{tabular}

When Table 1 is examined, it is seen that 213 of the attendees are female while 187 of them are male and 200 of them are studying at Religious Vocational Secondary School while 200 of them are studying at other Secondary Schools.

When Table 2 is examined, it is seen that there is a significant difference statistically among the answers given by female and male attendees for the statement "I cannot make time for studying because of the problems regarding school" $(p=, 032)$. It is observed that male attendees experience this problem more frequently. There is not a significant difference statistically among the answers given by female and male attendees for other problems regarding school $(p>0,05)$.

Table 2. Comparison of the Problems Encountered during Physical Education and Sports Activities regarding School Life by Gender

\begin{tabular}{|c|c|c|c|c|c|c|}
\hline \multirow{2}{*}{ Problems } & \multirow{2}{*}{ Answers } & \multirow{2}{*}{ Descriptive Statistic } & \multicolumn{2}{|c|}{ Gender } & \multirow{2}{*}{ Total } & \multirow{2}{*}{ Significance } \\
\hline & & & Female & Male & & \\
\hline \multirow{6}{*}{ I cannot make sufficient time for studying. } & \multirow{3}{*}{ Yes } & $\mathrm{F}$ & 44 & 56 & 100 & \multirow{6}{*}{$\begin{array}{c}x^{2}=4,58 \\
d f=1 \\
p=, 032\end{array}$} \\
\hline & & $(\%)$ Row & 44,0 & 56,0 & 100,0 & \\
\hline & & $(\%)$ Column & 20,7 & 29,9 & 25,0 & \\
\hline & \multirow{3}{*}{ No } & $\mathrm{F}$ & 169 & 131 & 300 & \\
\hline & & $(\%)$ Row & 56,3 & 43,7 & 100,0 & \\
\hline & & $(\%)$ Column & 79,3 & 70,1 & 75,0 & \\
\hline \multirow{6}{*}{ I fail in my lessons. } & \multirow{3}{*}{ Yes } & $\mathrm{F}$ & 39 & 43 & 82 & \multirow{6}{*}{$\begin{array}{c}\mathrm{x}^{2}=1,34 \\
\mathrm{df}=1 \\
\mathrm{p}=, 247\end{array}$} \\
\hline & & $(\%)$ Row & 47,6 & 52,4 & 100,0 & \\
\hline & & (\%)Column & 18,3 & 23,0 & 20,5 & \\
\hline & \multirow{3}{*}{ No } & $\mathrm{F}$ & 174 & 144 & 318 & \\
\hline & & (\%)Row & 54,7 & 45,3 & 100,0 & \\
\hline & & (\%)Column & 81,7 & 77,0 & 79,5 & \\
\hline \multirow{6}{*}{$\begin{array}{l}\text { The necessary importance is not attached to } \\
\text { physical education and sports activities at } \\
\text { school. }\end{array}$} & \multirow{3}{*}{ Yes } & $\mathrm{F}$ & 100 & 88 & 188 & \multirow{6}{*}{$\begin{array}{c}\mathrm{x}^{2}=, 00 \\
\mathrm{df}=1 \\
\mathrm{p}=, 982\end{array}$} \\
\hline & & $(\%)$ Row & 53,2 & 46,8 & 100,0 & \\
\hline & & (\%)Column & 46,9 & 47,1 & 47,0 & \\
\hline & \multirow{3}{*}{ No } & $\mathrm{F}$ & 113 & 99 & 212 & \\
\hline & & $(\%)$ Row & 53,3 & 46,7 & 100,0 & \\
\hline & & (\%)Column & 53,1 & 52,9 & 53,0 & \\
\hline \multirow{6}{*}{$\begin{array}{l}\text { There is not a convenient environment for } \\
\text { physical education and sports activities at } \\
\text { school. }\end{array}$} & \multirow{3}{*}{ Yes } & F & 65 & 68 & 133 & \multirow{6}{*}{$\begin{array}{c}\mathrm{x}^{2}=1,53 \\
\mathrm{df}=1 \\
\mathrm{p}=, 216\end{array}$} \\
\hline & & (\%)Row & 48,9 & 51,1 & 100,0 & \\
\hline & & (\%)Column & 30,5 & 36,4 & 33,3 & \\
\hline & \multirow{3}{*}{ No } & $\mathrm{F}$ & 148 & 119 & 267 & \\
\hline & & $(\%)$ Row & 55,4 & 44,6 & 100,0 & \\
\hline & & (\%)Column & 69,5 & 63,6 & 66,8 & \\
\hline \multirow{6}{*}{$\begin{array}{l}\text { There are problems about sports facility and } \\
\text { tools-devices at school. }\end{array}$} & \multirow{3}{*}{ Yes } & $\mathrm{F}$ & 79 & 73 & 152 & \multirow{6}{*}{$\begin{array}{c}x^{2}=, 16 \\
d f=1 \\
p=, 698\end{array}$} \\
\hline & & (\%)Row & 52,0 & 48,0 & 100,0 & \\
\hline & & $(\%)$ Column & 37,1 & 39,0 & 38,0 & \\
\hline & \multirow{3}{*}{ No } & $\mathrm{F}$ & 134 & 114 & 248 & \\
\hline & & $(\%)$ Row & 54,0 & 46,0 & 100,0 & \\
\hline & & (\%)Column & 62,9 & 61,0 & 62,0 & \\
\hline
\end{tabular}


Students in Physical Education and Sports Activities

Table 3. Comparison of the Problems Encountered during Physical Education and Sports Activities regarding Organizations and Institutions by Gender

\begin{tabular}{|c|c|c|c|c|c|c|}
\hline \multirow{2}{*}{ Problems } & \multirow{2}{*}{ Answers } & \multirow{2}{*}{ Descriptive Statistic } & \multicolumn{2}{|c|}{ Gender } & \multirow{2}{*}{ Total } & \multirow{2}{*}{ Significance } \\
\hline & & & Female & Male & & \\
\hline \multirow{6}{*}{$\begin{array}{l}\text { Educational level of those giving } \\
\text { sports training in the clubs is not } \\
\text { sufficient. }\end{array}$} & \multirow{3}{*}{ Yes } & $\mathrm{F}$ & 70 & 79 & 149 & \multirow{6}{*}{$\begin{array}{c}\mathrm{x}^{2}=3,75 \\
\mathrm{df}=1 \\
\mathrm{p}=, 053\end{array}$} \\
\hline & & (\%)Row & 47,0 & 53,0 & 100,0 & \\
\hline & & (\%)Column & 32,9 & 42,2 & 37,3 & \\
\hline & \multirow{3}{*}{ No } & $\mathrm{F}$ & 143 & 108 & 251 & \\
\hline & & $(\%)$ Row & 57,0 & 43,0 & 100,0 & \\
\hline & & (\%)Column & 67,1 & 57,8 & 62,8 & \\
\hline \multirow{6}{*}{$\begin{array}{l}\text { Educational level of those working in } \\
\text { sports facilities is not sufficient. }\end{array}$} & \multirow{3}{*}{ Yes } & $\mathrm{F}$ & 66 & 79 & 145 & \multirow{6}{*}{$\begin{array}{c}x^{2}=5,46 \\
d f=1 \\
p=, 019\end{array}$} \\
\hline & & (\%)Row & 45,5 & 54,5 & 100,0 & \\
\hline & & (\%)Column & 31,0 & 42,2 & 36,3 & \\
\hline & \multirow{3}{*}{ No } & $\mathrm{F}$ & 147 & 108 & 255 & \\
\hline & & (\%)Row & 57,6 & 42,4 & 100,0 & \\
\hline & & (\%)Column & 69,0 & 57,8 & 63,8 & \\
\hline \multirow{6}{*}{$\begin{array}{l}\text { Insufficiency of the facilities prevents } \\
\text { me from getting physical education } \\
\text { and performing sports activities more } \\
\text { efficiently. }\end{array}$} & \multirow{3}{*}{ Yes } & $\mathrm{F}$ & 86 & 97 & 183 & \multirow{6}{*}{$\begin{array}{c}\mathrm{x}^{2}=5,302 \\
\mathrm{df}=1 \\
\mathrm{p}=, 021\end{array}$} \\
\hline & & $(\%)$ Row & 47,0 & 53,0 & 100,0 & \\
\hline & & (\%)Column & 40,4 & 51,9 & 45,8 & \\
\hline & \multirow{3}{*}{ No } & $\mathrm{F}$ & 127 & 90 & 217 & \\
\hline & & $(\%)$ Row & 58,5 & 41,5 & 100,0 & \\
\hline & & (\%)Column & 59,6 & 48,1 & 54,3 & \\
\hline \multirow{6}{*}{$\begin{array}{l}\text { Cleaning and maintenance of the } \\
\text { current sports facilities is not } \\
\text { sufficient. }\end{array}$} & \multirow{3}{*}{ Yes } & $\mathrm{F}$ & 93 & 90 & 183 & \multirow{6}{*}{$\begin{array}{c}x^{2}=800 \\
d f=1 \\
p=, 371\end{array}$} \\
\hline & & (\%)Row & 50,8 & 49,2 & 100,0 & \\
\hline & & (\%)Column & 43,7 & 48,1 & 45,8 & \\
\hline & \multirow{3}{*}{ No } & $\mathrm{F}$ & 120 & 97 & 217 & \\
\hline & & $(\%)$ Row & 55,3 & 44,7 & 100,0 & \\
\hline & & $(\%)$ Column & 56,3 & 51,9 & 54,3 & \\
\hline \multirow{6}{*}{$\begin{array}{l}\text { Sports branches except from football } \\
\text { are not taking place sufficiently in the } \\
\text { media. }\end{array}$} & \multirow{3}{*}{ Yes } & $\mathrm{F}$ & 104 & 97 & 201 & \\
\hline & & $(\%)$ Row & 51,7 & 48,3 & 100,0 & \\
\hline & & $(\%)$ Column & 48,8 & 51,9 & 50,3 & $x^{2}=, 36$ \\
\hline & & $\mathrm{F}$ & 109 & 90 & 199 & $\mathrm{p}=, 543$ \\
\hline & No & $(\%)$ Row & 54,8 & 45,2 & 100,0 & \\
\hline & & (\%)Column & 51,2 & 48,1 & 49,8 & \\
\hline & & $\mathrm{F}$ & 115 & 107 & 222 & \\
\hline & Yes & $(\%)$ Row & 51,8 & 48,2 & 100,0 & \\
\hline Encouraging and educative programs & & $(\%)$ Column & 54,0 & 57,2 & 55,5 & $x^{2}=, 42$ \\
\hline of the media are insufficient. & & $\mathrm{F}$ & 98 & 80 & 178 & $\mathrm{p}=, 517$ \\
\hline & No & $(\%)$ Row & 55,1 & 44,9 & 100,0 & \\
\hline & & (\%)Column & 46,0 & 42,8 & 44,5 & \\
\hline & & $\mathrm{F}$ & 105 & 107 & 212 & \\
\hline There & Yes & $(\%)$ Row & 49,5 & 50,5 & 100,0 & \\
\hline media in which young & & $(\%)$ Column & 49,3 & 57,2 & 53,0 & $x^{2}=2,41$ \\
\hline sportsmen/sportswomen can express & & $\mathrm{F}$ & 108 & 80 & 188 & $\mathrm{p}=, 113$ \\
\hline & No & $(\%)$ Row & 57,4 & 42,6 & 100,0 & \\
\hline & & (\%)Column & 50,7 & 42,8 & 47,0 & \\
\hline
\end{tabular}


When Table 3 is examined, it is seen that there is a significant difference statistically among the answers given for the problems encountered by the attendees regarding organizations and institutions that educational level of the personnel working in sports facilities is not sufficient $(p=, 019)$ and the facilities are insufficient $(p=, 021)$. It is observed that both problems are experienced by male attendees more frequently. There is not a significant difference statistically among the answers given by female and male attendees for other problems regarding organizations and institutions ( $>0,05)$.

When Table 4 is examined, it is seen that among the problems experienced by the attendees, "My family tells me to finish my school first and then I can go in for sports" $(p=, 000)$ problem and "My family thinks that physical education and sports activities affect my lessons negatively" $(p=, 022)$ problem and "Family's not creating the necessary conditions for physical education and sports activities" $(p=, 000)$ problem are experienced significantly in a higher level in male attendees when compared to female attendees.

Table 4. Comparison of the Problems Encountered during Physical Education and Sports Activities regarding Family Life by Gender

\begin{tabular}{|c|c|c|c|c|c|c|}
\hline \multirow{2}{*}{ Problems } & \multirow{2}{*}{ Answers } & \multirow{2}{*}{$\begin{array}{l}\text { Descriptive } \\
\text { Statistic }\end{array}$} & \multicolumn{2}{|c|}{ Gender } & \multirow{2}{*}{ Total } & \multirow{2}{*}{ Significance } \\
\hline & & & Female & Male & & \\
\hline \multirow{6}{*}{$\begin{array}{l}\text { My family tells me to finish my school } \\
\text { first and then I can go in for sports. }\end{array}$} & \multirow{3}{*}{ Yes } & $\mathrm{F}$ & 69 & 100 & 169 & \multirow{6}{*}{$\begin{array}{c}\mathrm{x}^{2}=18,13 \\
\mathrm{df}=1 \\
\mathrm{p}=, 000\end{array}$} \\
\hline & & (\%)Row & 40,8 & 59,2 & 100,0 & \\
\hline & & $(\%)$ Column & 32,4 & 53,5 & 42,3 & \\
\hline & \multirow{3}{*}{ No } & $\mathrm{F}$ & 144 & 87 & 231 & \\
\hline & & (\%)Row & 62,3 & 37,7 & 100,0 & \\
\hline & & $(\%)$ Column & 67,6 & 46,5 & 57,8 & \\
\hline \multirow{6}{*}{$\begin{array}{l}\text { My family does not consider sports as an } \\
\text { occupation. }\end{array}$} & \multirow{3}{*}{ Yes } & $\mathrm{F}$ & 84 & 81 & 165 & \multirow{6}{*}{$\begin{array}{c}\mathrm{x}^{2}=, 618 \\
\mathrm{df}=1 \\
\mathrm{p}=, 432\end{array}$} \\
\hline & & (\%)Row & 50,9 & 49,1 & 100,0 & \\
\hline & & (\%)Column & 39,4 & 43,3 & 41,3 & \\
\hline & \multirow{3}{*}{ No } & $\mathrm{F}$ & 129 & 106 & 235 & \\
\hline & & (\%)Row & 54,9 & 45,1 & 100,0 & \\
\hline & & (\%)Column & 60,6 & 56,7 & 58,8 & \\
\hline \multirow{6}{*}{$\begin{array}{l}\text { My family thinks that physical education } \\
\text { and sports activities affect my lessons } \\
\text { negatively. }\end{array}$} & \multirow{3}{*}{ Yes } & $\mathrm{F}$ & 57 & 70 & 127 & \multirow{6}{*}{$\begin{array}{c}\mathrm{x}^{2}=5,23 \\
\mathrm{df}=1 \\
\mathrm{p}=, 022\end{array}$} \\
\hline & & (\%)Row & 44,9 & 55,1 & 100,0 & \\
\hline & & (\%)Column & 26,8 & 37,4 & 31,8 & \\
\hline & \multirow{3}{*}{ No } & $\mathrm{F}$ & 156 & 117 & 273 & \\
\hline & & (\%)Row & 57,1 & 42,9 & 100,0 & \\
\hline & & (\%)Column & 73,2 & 62,6 & 68,3 & \\
\hline \multirow{6}{*}{$\begin{array}{l}\text { I am of the opinion that my family's not } \\
\text { creating the necessary conditions for } \\
\text { physical education and sports activities } \\
\text { affect my physical and mental } \\
\text { development negatively. }\end{array}$} & \multirow{3}{*}{ Yes } & $\mathrm{F}$ & 42 & 68 & 110 & \multirow{6}{*}{$\begin{array}{c}\mathrm{x}^{2}=13,83 \\
\mathrm{df}=1 \\
\mathrm{p}=, 000\end{array}$} \\
\hline & & $(\%)$ Row & 38,2 & 61,8 & 100,0 & \\
\hline & & $(\%)$ Column & 19,7 & 36,4 & 27,5 & \\
\hline & \multirow{3}{*}{ No } & $\mathrm{F}$ & 171 & 119 & 290 & \\
\hline & & (\%)Row & 59,0 & 41,0 & 100,0 & \\
\hline & & (\%)Column & 80,3 & 63,6 & 72,5 & \\
\hline
\end{tabular}


Table 5. Comparison of the Problems Encountered during Physical Education and Sports Activities regarding School Life by School Type

\begin{tabular}{|c|c|c|c|c|c|c|}
\hline \multirow[b]{2}{*}{ Problems } & \multirow[b]{2}{*}{ Answers } & \multirow{2}{*}{$\begin{array}{c}\text { Descriptive } \\
\text { Statistic }\end{array}$} & \multicolumn{2}{|c|}{ School Type } & \multirow[b]{2}{*}{ Total } & \multirow[b]{2}{*}{ Significance } \\
\hline & & & $\begin{array}{c}\text { Religious } \\
\text { Vocational }\end{array}$ & $\begin{array}{c}\text { Secondary } \\
\text { School }\end{array}$ & & \\
\hline \multirow{6}{*}{$\begin{array}{l}\text { I cannot make } \\
\text { sufficient time for } \\
\text { studying. }\end{array}$} & \multirow{3}{*}{ Yes } & $\mathrm{F}$ & 45 & 55 & 100 & \multirow{6}{*}{$\begin{array}{c}\mathrm{x}^{2}=1,33 \\
\mathrm{df}=1 \\
\mathrm{p}=, 248\end{array}$} \\
\hline & & (\%)Row & 45,0 & 55,0 & 100,0 & \\
\hline & & $(\%)$ Column & 22,5 & 27,5 & 25,0 & \\
\hline & \multirow{3}{*}{ No } & $\mathrm{F}$ & 155 & 145 & 300 & \\
\hline & & $(\%)$ Row & 51,7 & 48,3 & 100,0 & \\
\hline & & $(\%)$ Column & 77,5 & 72,5 & 75,0 & \\
\hline \multirow{6}{*}{ I fail in my lessons. } & \multirow{3}{*}{ Yes } & $\mathrm{F}$ & 41 & 41 & 82 & \multirow{6}{*}{$\begin{array}{c}\mathrm{x}^{2}=, 00 \\
\mathrm{df}=1 \\
\mathrm{p}=1,0\end{array}$} \\
\hline & & $(\%)$ Row & 50,0 & 50,0 & 100,0 & \\
\hline & & $(\%)$ Column & 20,5 & 20,5 & 20,5 & \\
\hline & \multirow{3}{*}{ No } & $\mathrm{F}$ & 159 & 159 & 318 & \\
\hline & & $(\%)$ Row & 50,0 & 50,0 & 100,0 & \\
\hline & & $(\%)$ Column & 79,5 & 79,5 & 79,5 & \\
\hline \multirow{6}{*}{$\begin{array}{l}\text { The necessary } \\
\text { importance is not } \\
\text { attached to physical } \\
\text { education and sports } \\
\text { activities at school. }\end{array}$} & \multirow{3}{*}{ Yes } & $\mathrm{F}$ & 96 & 92 & 188 & \multirow{6}{*}{$\begin{array}{c}x^{2}=, 161 \\
d f=1 \\
p=, 689\end{array}$} \\
\hline & & $(\%)$ Row & 51,1 & 48,9 & 100,0 & \\
\hline & & $(\%)$ Column & 48,0 & 46,0 & 47,0 & \\
\hline & \multirow{3}{*}{ No } & $\mathrm{F}$ & 104 & 108 & 212 & \\
\hline & & $(\%)$ Row & 49,1 & 50,9 & 100,0 & \\
\hline & & $(\%)$ Column & 52,0 & 54,0 & 53,0 & \\
\hline \multirow{6}{*}{$\begin{array}{l}\text { There is not a } \\
\text { convenient } \\
\text { environment for } \\
\text { physical education and } \\
\text { sports activities at } \\
\text { school. }\end{array}$} & \multirow{3}{*}{ Yes } & $\mathrm{F}$ & 69 & 64 & 133 & \multirow{6}{*}{$\begin{array}{c}x^{2}=, 282 \\
d f=1 \\
p=, 596\end{array}$} \\
\hline & & $(\%)$ Row & 51,9 & 48,1 & 100,0 & \\
\hline & & $(\%)$ Column & 34,5 & 32,0 & 33,3 & \\
\hline & \multirow{3}{*}{ No } & $\mathrm{F}$ & 131 & 136 & 267 & \\
\hline & & $(\%)$ Row & 49,1 & 50,9 & 100,0 & \\
\hline & & $(\%)$ Column & 65,5 & 68,0 & 66,8 & \\
\hline \multirow{6}{*}{$\begin{array}{l}\text { There are problems } \\
\text { about sports facility and } \\
\text { tools-devices at school. }\end{array}$} & \multirow{3}{*}{ Yes } & $\mathrm{F}$ & 69 & 83 & 152 & \multirow{6}{*}{$\begin{array}{c}x^{2}=2,08 \\
d f=1 \\
p=, 149\end{array}$} \\
\hline & & $(\%)$ Row & 45,4 & 54,6 & 100,0 & \\
\hline & & $(\%)$ Column & 34,5 & 41,5 & 38,0 & \\
\hline & \multirow{3}{*}{ No } & $\mathrm{F}$ & 131 & 117 & 248 & \\
\hline & & $(\%)$ Row & 52,8 & 47,2 & 100,0 & \\
\hline & & (\%)Column & 65,5 & 58,5 & 62,0 & \\
\hline
\end{tabular}

When Table 5 is examined, the problems encountered by the students studying at Religious Vocational Secondary School and other secondary school during physical education and sports activities regarding school life such as "I cannot make sufficient time for studying" $(p=, 248)$, "I fail in my lessons $(p=1,0)$, "The necessary importance is not attached to physical education and sports activities at school" $(p=, 689)$, "There is not a convenient environment for physical education and sports activities at school" $(p=, 596)$, "There are problems about sports facility and tools-devices at school" $(\mathrm{p}=, 149)$ do not differ by school type statistically.

When Table 6 is examined, it is seen that among the problems experienced by the attendees regarding organizations and institutions, the answers given for the statement "Sports branches except from football are not taking place sufficiently in the media" $(p=, 057)$ do not differ by school type in a significant level statistically $(\mathrm{p}>0,05)$; on the other hand the problems "Educational level of those giving sports training in the clubs is not sufficient" $(p=, 000)$, "Educational level of those working in sports facilities is not sufficient" ( $p=, 017)$, "Insufficiency of the facilities prevents me from getting physical education and performing sports activities more efficiently" $(p=, 001)$, "Cleaning and maintenance of the current sports facilities is not sufficient" $(p=, 000)$, "Encouraging and educative programs of the media are insufficient" $(\mathrm{p}=, 005)$, "There are not any programs in the media in which young sportsmen/sportswomen can express their problems" $(\mathrm{p}=, 028)$ differ in a significant level statistically $(\mathrm{p}<0,05)$ and students studying at secondary school experience these problems more frequently than students studying at Religious Vocational Secondary School. 
Table 6. Comparison of the Problems Encountered during Physical Education and Sports Activities regarding Organizations and Institutions by School Type

\begin{tabular}{|c|c|c|c|c|c|c|}
\hline \multirow[b]{2}{*}{ Problems } & \multirow[b]{2}{*}{ Answers } & \multirow[b]{2}{*}{ Descriptive Statistic } & \multicolumn{2}{|c|}{ School Type } & \multirow[b]{2}{*}{ Total } & \multirow[b]{2}{*}{ Significance } \\
\hline & & & $\begin{array}{c}\text { Religious } \\
\text { Vocational }\end{array}$ & $\begin{array}{c}\text { Secondary } \\
\text { School }\end{array}$ & & \\
\hline \multirow{6}{*}{$\begin{array}{l}\text { Educational level of those } \\
\text { giving sports training in } \\
\text { the clubs is not sufficient. }\end{array}$} & \multirow{3}{*}{ Yes } & $\mathrm{F}$ & 56 & 93 & 149 & \multirow{6}{*}{$\begin{array}{c}\mathrm{x}^{2}=14,64 \\
\mathrm{df}=1 \\
\mathrm{p}=, 000\end{array}$} \\
\hline & & (\%)Row & 37,6 & 62,4 & 100,0 & \\
\hline & & (\%)Column & 28,0 & 46,5 & 37,3 & \\
\hline & \multirow{3}{*}{ No } & $\mathrm{F}$ & 144 & 107 & 251 & \\
\hline & & $(\%)$ Row & 57,4 & 42,6 & 100,0 & \\
\hline & & (\%)Column & 72,0 & 53,5 & 62,8 & \\
\hline \multirow{6}{*}{$\begin{array}{l}\text { Educational level of those } \\
\text { working in sports facilities } \\
\text { is not sufficient. }\end{array}$} & \multirow{3}{*}{ Yes } & $\mathrm{F}$ & 61 & 84 & 145 & \multirow{6}{*}{$\begin{array}{c}x^{2}=5,72 \\
d f=1 \\
p=, 017\end{array}$} \\
\hline & & $(\%)$ Row & 42,1 & 57,9 & 100,0 & \\
\hline & & (\%)Column & 30,5 & 42,0 & 36,3 & \\
\hline & \multirow{3}{*}{ No } & $\mathrm{F}$ & 139 & 116 & 255 & \\
\hline & & (\%)Row & 54,5 & 45,5 & 100,0 & \\
\hline & & $(\%)$ Column & 69,5 & 58,0 & 63,8 & \\
\hline \multirow{6}{*}{$\begin{array}{l}\text { Insufficiency of the } \\
\text { facilities prevents me from } \\
\text { getting physical education } \\
\text { and performing sports } \\
\text { activities more efficiently. }\end{array}$} & \multirow{3}{*}{ Yes } & $\mathrm{F}$ & 75 & 108 & 183 & \multirow{6}{*}{$\begin{array}{c}x^{2}=10,96 \\
d f=1 \\
p=, 001\end{array}$} \\
\hline & & $(\%)$ Row & 41,0 & 59,0 & 100,0 & \\
\hline & & $(\%)$ Column & 37,5 & 54,0 & 45,8 & \\
\hline & \multirow{3}{*}{ No } & $\mathrm{F}$ & 125 & 92 & 217 & \\
\hline & & $(\%)$ Row & 57,6 & 42,4 & 100,0 & \\
\hline & & $(\%)$ Column & 62,5 & 46,0 & 54,3 & \\
\hline \multirow{6}{*}{$\begin{array}{l}\text { Cleaning and maintenance } \\
\text { of the current sports } \\
\text { facilities is not sufficient. }\end{array}$} & \multirow{3}{*}{ Yes } & $\mathrm{F}$ & 72 & 111 & 183 & \multirow{6}{*}{$\begin{array}{c}\mathrm{x}^{2}=15,32 \\
\mathrm{df}=1 \\
\mathrm{p}=, 000\end{array}$} \\
\hline & & (\%)Row & 39,3 & 60,7 & 100,0 & \\
\hline & & $(\%)$ Column & 36,0 & 55,5 & 45,8 & \\
\hline & \multirow{3}{*}{ No } & $\mathrm{F}$ & 128 & 89 & 217 & \\
\hline & & $(\%)$ Row & 59,0 & 41,0 & 100,0 & \\
\hline & & $(\%)$ Column & 64,0 & 44,5 & 54,3 & \\
\hline \multirow{6}{*}{$\begin{array}{c}\text { Sports branches except } \\
\text { from football are not taking } \\
\text { place sufficiently in the } \\
\text { media. }\end{array}$} & \multirow{3}{*}{ Yes } & $F$ & 91 & 110 & 201 & \\
\hline & & $(\%)$ Row & 45,3 & 54,7 & 100,0 & \\
\hline & & (\%)Column & 45,5 & 55,0 & 50,3 & $x^{2}=3,61$ \\
\hline & & $\mathrm{F}$ & 109 & 90 & 199 & $\begin{array}{c}\mathrm{dr}=1 \\
\mathrm{p}=.057\end{array}$ \\
\hline & No & $(\%)$ Row & 54,8 & 45,2 & 100,0 & \\
\hline & & $(\%)$ Column & 54,5 & 45,0 & 49,8 & \\
\hline & & $\mathrm{F}$ & 97 & 125 & 222 & \\
\hline & Yes & $(\%)$ Row & 43,7 & 56,3 & 100,0 & \\
\hline Encouraging and educative & & (\%)Column & 48,5 & 62,5 & 55,5 & $x^{2}=7,93$ \\
\hline $\begin{array}{l}\text { programs or the media are } \\
\text { insufficient. }\end{array}$ & & $\mathrm{F}$ & 103 & 75 & 178 & $\begin{array}{c}\mathrm{dr}=1 \\
\mathrm{p}=, 005\end{array}$ \\
\hline & No & (\%)Row & 57,9 & 42,1 & 100,0 & \\
\hline & & (\%)Column & 51,5 & 37,5 & 44,5 & \\
\hline & & $\mathrm{F}$ & 95 & 117 & 212 & \\
\hline There are not any programs & Yes & $(\%)$ Row & 44,8 & 55,2 & 100,0 & \\
\hline in the media in which & & $(\%)$ Column & 47,5 & 58,5 & 53,0 & $\mathrm{x}^{2}=4,85$ \\
\hline $\begin{array}{c}\text { young } \\
\text { sportsmen/sportswomen }\end{array}$ & & $\mathrm{F}$ & 105 & 83 & 188 & $\mathrm{p}=, 028$ \\
\hline can express their problems. & No & $(\%)$ Row & 55,9 & 44,1 & 100,0 & \\
\hline & & $(\%)$ Column & 52,5 & 41,5 & 47,0 & \\
\hline
\end{tabular}


Students in Physical Education and Sports Activities

Table 7. Comparison of the Problems Encountered during Physical Education and Sports Activities regarding Family Life by School Type

\begin{tabular}{|c|c|c|c|c|c|c|}
\hline \multirow[b]{2}{*}{ Problems } & \multirow[b]{2}{*}{ Answers } & \multirow[b]{2}{*}{ Descriptive Statistic } & \multicolumn{2}{|c|}{ School Type } & \multirow[b]{2}{*}{ Total } & \multirow[b]{2}{*}{ Significance } \\
\hline & & & $\begin{array}{c}\text { Religious } \\
\text { Vocational } \\
\end{array}$ & $\begin{array}{c}\text { Secondary } \\
\text { School }\end{array}$ & & \\
\hline \multirow{6}{*}{$\begin{array}{l}\text { My family tells me to finish my } \\
\text { school first and then I can go in for } \\
\text { sports. }\end{array}$} & \multirow{3}{*}{ Yes } & $\mathrm{F}$ & 76 & 93 & 169 & \multirow{6}{*}{$\begin{array}{c}x^{2}=2,96 \\
d f=1 \\
p=, 085\end{array}$} \\
\hline & & (\%)Row & 45,0 & 55,0 & 100,0 & \\
\hline & & (\%)Column & 38,0 & 46,5 & 42,3 & \\
\hline & \multirow{3}{*}{ No } & $\mathrm{F}$ & 124 & 107 & 231 & \\
\hline & & $(\%)$ Row & 53,7 & 46,3 & 100,0 & \\
\hline & & $(\%)$ Column & 62,0 & 53,5 & 57,8 & \\
\hline \multirow{6}{*}{$\begin{array}{l}\text { My family does not consider sports } \\
\text { as an occupation. }\end{array}$} & \multirow{3}{*}{ Yes } & $\mathrm{F}$ & 73 & 92 & 165 & \multirow{6}{*}{$\begin{array}{c}x^{2}=3,72 \\
d f=1 \\
p=, 054\end{array}$} \\
\hline & & $(\%)$ Row & 44,2 & 55,8 & 100,0 & \\
\hline & & (\%)Column & 36,5 & 46,0 & 41,3 & \\
\hline & \multirow{3}{*}{ No } & $\mathrm{F}$ & 127 & 108 & 235 & \\
\hline & & $(\%)$ Row & 54,0 & 46,0 & 100,0 & \\
\hline & & $(\%)$ Column & 63,5 & 54,0 & 58,8 & \\
\hline \multirow{6}{*}{$\begin{array}{l}\text { My family thinks that physical } \\
\text { education and sports activities affect } \\
\text { my lessons negatively. }\end{array}$} & \multirow{3}{*}{ Yes } & $\mathrm{F}$ & 52 & 75 & 127 & \multirow{6}{*}{$\begin{array}{c}\mathrm{x}^{2}=6,10 \\
\mathrm{df}=1 \\
\mathrm{p}=, 013\end{array}$} \\
\hline & & (\%)Row & 40,9 & 59,1 & 100,0 & \\
\hline & & $(\%)$ Column & 26,0 & 37,5 & 31,8 & \\
\hline & \multirow{3}{*}{ No } & $\mathrm{F}$ & 148 & 125 & 273 & \\
\hline & & $(\%)$ Row & 54,2 & 45,8 & 100,0 & \\
\hline & & $(\%)$ Column & 74,0 & 62,5 & 68,3 & \\
\hline \multirow{6}{*}{$\begin{array}{l}\text { I am of the opinion that my family's } \\
\text { not creating the necessary } \\
\text { conditions for physical education } \\
\text { and sports activities affect my } \\
\text { physical and mental development } \\
\text { negatively. }\end{array}$} & \multirow{3}{*}{ Yes } & $\mathrm{F}$ & 37 & 73 & 110 & \multirow{6}{*}{$\begin{array}{c}\mathrm{x}^{2}=16,25 \\
\mathrm{df}=1 \\
\mathrm{p}=, 000\end{array}$} \\
\hline & & $(\%)$ Row & 33,6 & 66,4 & 100,0 & \\
\hline & & (\%)Column & 18,5 & 36,5 & 27,5 & \\
\hline & \multirow{3}{*}{ No } & $\mathrm{F}$ & 163 & 127 & 290 & \\
\hline & & $(\%)$ Row & 56,2 & 43,8 & 100,0 & \\
\hline & & (\%)Column & 81,5 & 63,5 & 72,5 & \\
\hline
\end{tabular}

\section{Discussion, Conclusions and Recommendations}

213 female and 187 male students attended to the research and 200 of these are studying at Religious Vocational Secondary school while 200 of them are studying at other secondary school. It is observed that as long as they perform sports, male students are experiencing the problem of not making enough time for studying when compared to female students (Table 2).It is seen that the problems regarding organizations and institutions such as insufficiency of the personnel working in sports facilities and insufficiency of the facilities are experienced by male students more frequently compared to female students (Table 3). Similar results are seen in Pehlivan's (2009) study[19].It is seen that the problems regarding family such as family's first asking them to finish their school and then go in for sports and family's thinking that physical education and sports activities affect their lessons negatively are experienced by male students more frequently compared to female students (Table 4).

It is seen that students studying at Religious Vocational
Secondary School and other Secondary School experience the problems in the same level such as not making enough time for studying during the process of attending physical education and sports activities, failing in lessons, not attaching the necessary importance to physical education and sports activities at school, not providing convenient environment for physical education and sports activities at school and insufficient sports facilities and tools-devices at school (Table 5). Similar results are seen in Hergüner's (2001) study[20].

It is seen that students agree with each other about the problem that sports branches except from football are not taking place sufficiently in the media which is experienced by students studying at Religious Vocational Secondary School and other Secondary School regarding organizations and institutions; however students studying at other Secondary School when compared to Religious Vocational Secondary School experience more frequently the problems of insufficient educational level of those giving sports training in the clubs, insufficient educational level of those working in sports facilities, insufficiency of the facilities' 
preventing them from getting physical education and performing sports activities more efficiently, insufficiency of encouraging and educative programs of the media, unavailability of the programs in the media in which young sportsmen/sportswomen can express their problems (Table 6). This result shows parallelism with the study of Mamak (2010)[21]. Furthermore, Kenyon and Pherson (1973)[22].think that as the facilities and opportunity for doing sports increase in the environment, individuals' habit of doing sports will increase in the same extent. Generally, low number of certified sportsmen/sportswomen at our schools can be explained as the result of these problems. Central and local administrations authorized for sports in Turkey should increase investments for popularizing sports and facilities and maintenance and repair of the current facilities should be done periodically.

At the end of the research, when compared to female students, it is seen that male students experience the problems of "My family thinks that physical education and sports activities affect my lessons negatively" and "I am of the opinion that my family's not creating the necessary conditions for physical education and sports activities affect my physical and mental development negatively" more frequently in a significant level (Table 7) and these results coincide with the results of study carried out by Hergüner (1991)[12]. Moreover, it has been found that when compared to Religious Vocational Secondary School students, other Secondary School students experience the problems regarding family, organizations and institutions and school more frequently.

With this research, it has been observed male students while compared to female students and other Secondary School students when compared to Religious Vocational Secondary School students experience problems regarding attendance to physical education and sports activities more frequently. It can be said that these students experience problems in every field more frequently due to the fact that they attend physical education and sports activities more frequently.

Furthermore, although other secondary schools have more facilities in terms of sport complexes, equipment, sport branches which are practiced at the schools and the competitions the schools joined than the Religion Vocational Secondary Schools, they have more problems. Thus, it can be stated that the findings and the results are parallel with the facilities of the schools.

\section{Recommendations}

- School administration, guidance teachers and families should motivate and support students, especially male students, to use their time more efficiently in terms of both sports and studying.

- Convenient environment should be created for physical education and sports activities at schools and problems regarding sports facilities and tools-devices should be solved.

- Education levels of the individuals giving sports training in clubs and personnel working in sports facilities should be increased.

- Maintenance, repair and cleaning of the sports facilities in clubs and at schools should be performed routinely.

- Time for other sports branches except from football should be allocated in the media, encouraging and educative programs for sports should be increased in the media and programs in which young sportsmen/sportswomen can express their problems should be increased.

- Furthermore, awareness of school administrations, teachers and families should be raised about sports.

- Similar studies can be carried out at private schools and in other educational levels.

- In further researches, expectations and solutions regarding the problems determined in the study can be investigated.

\section{REFERENCES}

[1] ARSLAN R. Beden Eğitimi Bilgileri. 1979:102.

[2] BİLGE N. Türkiye'de Beden Eğitimi Öğretmeninin Yetiştirilmesi. 1st Edition, Kültür bakanlığı yayınları. 1989.

[3] PANGRAZZI RP. Dynamic Physical Education For Elementary School Children. Pearson Education Inc. 2007.

[4] ERKAL ME, GÜVEN Ö, AYAN D. Sosyolojik Açıdan Spor. Derya yayınları. 1998.

[5] AMMAN M. Kadın ve Spor. Marpa Kültür Yayınları. 2005.

[6] EKELAND E, HEİAN F, HAGEN KB. Can Exercise Improve Self Esteem in Children And Young People? A Systematic Review of Randomised Controlled Trials. British Journal of Sports Medicine. 2005:39.

[7] KARAKAYA I, COŞKUN A, AĞAOĞLU B. Yüzücülerin Depresyon, Benlik Saygısı Ve Kayg1 Düzeylerinin Değerlendirilmesi. Anadolu Psikiyatri Dergisi. 2006;7.

[8] HARMANDAR İH, ÖZDİLEK Ç, GÖRAL M. Beden Eğitimi ve Sporda Özel Öğretim Yöntemleri. Alp Ofset. 2000.

[9] HERGUNER G, BAR M, YAMAN MS. Beden eğitimi ve spor etkinliklerine katılan ortaokul öğrencilerinin aile, okul yöneticileri ve öğretmenlerden beklentilerinin belirlenmesi. International Journal of Human Sciences. 2016;1:13.

[10] ŞİMŞEK KY. Çocukların spora yönlendirilmesinde Ailenin Görüşlerinin Değerlendirilmesi (2005 Eskişehiril örneği). . Anadolu University, Institute of Health Sciences, Master's Thesis. 2005.

[11] ARACI H. Öğretmenler ve Öğrenciler İçin Okullarda Beden Eğitimi. BağırganYayıncılık. 2000.

[12] HERGÜNER G. Çocuğun Spora Yönelmesinde Ailenin Rolü Ve Önemi. On Dokuz Mayıs University, Faculty of Education Journal. 1991; 6: 89, 91. 
[13] KILCIGİL E. Sosyal Çevre- Spor İlişsileri. BağırganYayınevi. 1998:57.

[14] KARASÜLEYMANOĞLU A. Yeni Boyutlarıla Spor. OzanDağıtım. 1995:50.

[15] ROKACH A. Surviving and Coping with Loneliness. Journal of Psychology. 1989:124.

[16] HERGÜNER G. Eğitim-Spor İlişkisi. On Dokuz Mayıs University, Faculty of Education Journal. 1992; 7: 61.

[17] İlköğretim Okulları Haftalık Ders Çizelgesi. In: Bakanlığı ME, editor. Türkiye: Talim ve Terbiye Kurulu Başkanlığı; 2016.

[18] In:Ortaokulu SS-MDİH, editor. Türkiye: T.C. Millî Eğitim Bakanlığı; 2016.

[19] PEHLIVAN Z. Spora Katılan Çocuklara Yönelik Ailelerin
Beklentileri, Çocuklarda Gözlenen Davranış Değişimleri Ve Spora Katılımın Önündeki Engeller. Spormetre Beden Eğitimi Ve Spor Bilimleri Dergisi. 2009.

[20] HERGÜNER G. Farklı Liselerdeki Sporcu Öğrencilerin Problem Ve Beklentilerinin Belirlenmesi Ankara İl Örneği. Unpublished $\mathrm{PhD}$ Thesis, Gazi University, Institute of Health Sciences. 2001:92.

[21] MAMAK H. 8 Yıllık Kesintisiz İlköğretim Okullarında Beden Eğitimi Ve Spor Derslerinin Uygulanırlığı Ve Amaçlarına Ulaşma Düzeyi [Konya İli Uygulamas1]. Ankara, Gazi University, Institute of Educational Sciences, Department of Physical Education and Sports Teaching, PhD Thesis. 2010.

[22] KENYON GS, PHERSON M. "Becoming Involved in Physical Activity and Sport: A Process of Socialization", Physical Activity Human Growth and Development. New York, London, Academic Press. 1973. 